\title{
How James Kept the Pace?; A Look into the Organic Unity of Daisy Miller
}

\author{
Sina Movaghati (Corresponding author) \\ English Language and Literature Department, Kharazmi University of Tehran, Mofateh, Tehran, Iran \\ E-mail: sinamovaghati@yahoo.com \\ Milad Comcar \\ English Language and Literature Department, Kharazmi University of Tehran, Mofateh, Tehran, Iran \\ E-mail: comcar.milad@gmail.com
}

Doi:10.7575/aiac.alls.v.6n.6p.39

URL: http://dx.doi.org/10.7575/aiac.alls.v.6n.6p.39
Received: $15 / 06 / 2015$

Accepted: 28/08/2015

\begin{abstract}
Many Critics believe that Henry James has set the definitive standards of modern fiction writing. Undoubtedly his groundbreaking article "The Art of fiction," which published for the first time in 1884, has a major contribution in developing the theories of fiction writing. The term Organic Unity has derived from a major Formalist Critic, Cleanth Brooks. Both James and Brooks believed that a critic should approach a text as an organic whole. So, in this article we try to pinpoint the ideas which James and Brooks claimed in their essays and see how these ideas conform to one of James' well-known stories, Daisy Miller. We want to observe that how James develops and shapes his story around the central theme. Furthermore, we want to investigate that are there any literary devices embedded in the text of the story which help James to deliver his fiction with artistry?
\end{abstract}

Keywords: James, Cleanth Brooks, Organic Unity, The Art of Fiction, Daisy Miller

\section{Introduction}

\subsection{Organic Unity}

Organic Unity or Organic Form was one of the major topics of debates during the reign of the New Critics. The concept of organic unity was mentioned for the first time in such works as The Republic, Phaedrus, and Gorgias by the Greek philosopher Plato; but it lacked the true definitive role in literature until it was formed and shaped by another Greek philosopher, Aristotle. In Aristotle's Poetics, organic unity is described by "how writing relies internally on narration and drama to remain cohesive to one another, not as separate entities. Without balance on both sides, the whole concept suffers" (Britannica). A Dictionary of Literary and Thematic Terms defines organic unity as:

An argument that a literary work evolves and develops like a plant or other organism, naturally and internally. [...] The term was originally employed by Samuel Taylor Coleridge in defending Shakespeare from neoclassical critics' charges of formal flaws in his plays. Coleridge argues that Shakespeare's works exhibit "organic" rather than "mechanic" form: "The form is mechanic when, on any given material, we impress a predetermined form. The organic form, on the other hand, is innate; it shapes as it develops itself from within, and the fullness of its development is one and the same with the perfection of its outward form." The idea of the literary text as a living organism has been an influential concept in the 20th century, particularly in NEW CRITICISM. (Quinn, 2006, p.306)

\subsection{Claiming The Organic Unity in "The Art of Fiction"}

Henry James' critical essay, “The Art of Fiction” was published in Longman's Magazine in 1884. Actually, it was a reaction to a lecture which was given by Sir Walter Besant ${ }^{1}$ in 1884 , but James' essay became one of the most important essays in theory of fiction. James chose the title of the essay as a reaction to the title of Besant's lecture, too. ${ }^{2}$ He starts his essay by asserting his key critical point; he elucidates that the sole motive of the author for the fiction should be epitomizing real life with all its fragments. He remarks that "The only reason for the existence of a novel is that it does attempt to represent life" (James, 2010, p.745). He proceeds and declares that "the air of reality (solidity of specification) seems to me to be the supreme virtue of a novel" (James, 2010, p.750).

James continues his discussion by talking about form; he maintains that the author, like the painter and the artist, should capture life with all its particles and should illustrate it in his form of the novel, so one can judge a novel, not by his own taste but by the form which the author tries to produce; James maintains:

\footnotetext{
${ }^{1}$ Sir Walter Besant (1836 - 1901), was an English novelist and historian.

2 The title of Besant's lecture was The Art of Fiction, too; it seems that James chose the same title to mock Besant's opinions about novel and author.
} 
The cultivation of this success, the study of this exquisite process, form, to my taste, the beginning and the end of the art of the novelist. They are his inspiration, his despair, his reward, his torment, his delight. It is here, in very truth, that he competes with life; it is here that he competes with his brother the painter, in his attempt to render the look of things, the look that conveys their meaning, to catch the colour, the relief, the expression, the surface, the substance of the human spectacle. (James, 2010, p.751)

In this respect we can call him a Formalist and it is a fact that Formalists used James's critical point of views in order to strengthen their critical theories. Later, in his essay, James attacks Besant's standpoint about making a distinction about "incidents," "descriptions," and the "characters." James claims that there is no such thing as significant incidents and insignificant incidents; there is no such thing as significant characters and insignificant characters. Here, James asserts the idea of organic unity and maintains that all the characters, incidents, and descriptions are significant to the plot. He restates Coleridge point of view about a work of art (here particularly a novel) and argues that novel is a living thing and an organic whole which all its materials and substances come together to form an organism. James contends that

Nothing, for instance, is more possible than that he be of a turn of mind for which this odd, literal opposition of description and dialogue, incident and description, has little meaning and light. People often talk of these things as if they had a kind of internecine distinctness, instead of melting into each other at every breath and being intimately associated parts of one general effort of expression. I cannot imagine composition existing in a series of blocks, nor conceive, in any novel worth discussing at all, of a passage of description that is not in its intention narrative, a passage of dialogue that is not in its intention descriptive, a touch of truth of any sort that does not partake of the nature of incident, and an incident that derives its interest from any other source than the general and only source of the success of a work of art - that of being illustrative. A novel is a living thing, all one and continuous, like every other organism, and in proportion as it lives will it be found, I think, that in each of the parts there is something of each of the other parts. (James, 2010, p.751)

In the next few sentences he wrote these famous questions which became one of the landmarks in the theories of novel in the twentieth century: "What is character but the determination of incidents? What is incident but the illustration of character?" (James, 2010, p.752)

James maintains that the separation between novel and the romance, and the novel of incident and the novel of character are "clumsy separations" and only made by critics and certain readers for their own sake and convenience. James thinks that subject or idea of a novel should not be the subject of criticism; so he claims: "We must grant the artist his subject, his idea, donnée; our criticism is applied only to what he makes of it" (James, 2010, p.753). Again we can observe that, in James opinion, the crucial criteria for criticizing and judging a novel are those intrinsic features which the reader can see in the text, and not those features which are outside the text (like biography, politics,...) and imposed by certain critics when they are judging a literary text. Another thing which James mentions at the end of the essay is about this question that a novel should be moral or not? James confutes the whole idea and believes that it is not a goal for a novel to have certain moral lesson; One should judge a novel by the certain intrinsic features which the artist, as James calls a novelist, puts in his novel in order to achieve his own goal, which is the idea and the purpose which he pursues from writing the novel. Again this is a fact that proves James as a Formalist. Although we cannot call him a Formalist critic but certainly he and his opinions had certain tendencies toward formalism.

James maintains his argument by attacking Emile Zola's idea of the "treatment" of a novel. James argues that there is no such thing as good taste and bad taste in writing fiction, in his word he calls it "the absoluteness of taste;" and to him the motive of the author is above all things, and if the author has the success to achieve that motive, he will be able to show the real life to his readers, and readers can feel the art also; he believes that if the writers does not have creativity, they will sink into the well of familiar clichés. James writes:

Thinking that there are certain things that people ought to like, and that they can be made to like. I am quite at a loss to imagine anything (at any rate in this matter of fiction) that people ought to like or to dislike. Selection will be sure to take care of itself, for it has a constant motive behind it. That motive is simply experience. As people feel life, so they will feel the art that is most closely related to it. This closeness of relation is what we should never forget in talking of the effort of the novel. Many people speak of it as a factitious, artificial form, a product of ingenuity, the business of which is to alter and arrange the things that surround us, to translate them into conventional, traditional moulds. This, however, is a view of the matter which carries us but a very short way, condemns the art to an eternal repetition of a few familiar clichés, cuts short its development, and leads us straight up to a dead wall. Catching the very note and trick, the strange irregular rhythm of life, that is the attempt whose strenuous force keeps Fiction upon her feet. (James, 2010, p.754)

James believes that if an author wants to get rid of the problem of mediocrity he should have creativity; for James creativity goes along with freedom. He writes: "It appears to me that no one can ever have made a seriously artistic attempt without becoming conscious of an immense increase - a kind of revelation —of freedom" (James, 2010, p.754).

When the essay becomes close to its ending, James remarks that an author or a novelist should have the capacity to receive the straight impressions from his surroundings. He writes: "If he has taste, I must add, of course he will have ingenuity, [...] But it is only a secondary aid; the first is a capacity for receiving straight impressions" (James, 2010, p.755). He also, for the second time, talks about an organic whole and asserts that every line, every image, and even 
each punctuation mark contributes to the novel as a whole, so that the combination should be criticized rather than the individuals. James States:

This sense of the story being the idea, the starting-point, of the novel is the only one that I see in which it can be spoken of as something different from its organic whole; and since, in proportion as the work is successful, the idea permeates and penetrates it, informs and animates it, so that every word and every punctuation-point contribute directly to the expression, in that proportion do we lose our sense of the story being a blade which may be drawn more or less out of its sheath. The story and the novel, the idea and the form, are the needle and thread, and I never heard of a guild of tailors who recommended the use of the thread without the needle or the needle without the thread. (James, 2010, p.755)

Call him a realist, an impressionist or an expressionist, Henry James was truly a pioneer in modern fiction writing. Through the examination of his revolutionary essay "The Art of Fiction," we grasp certain few points about his critical standpoints about novel writing. 1- Novelist should not have any restriction according to their subject matter. 2- He should derive his subject matter from the real life experience or his surroundings 3- Author should treat his novel delicately and with artistry. 4- Judgments should not be based on moral matters or taste. 5- The Novel should be judged as a whole, and should not be judged based on the individual fragments or parts of it. 6- The author should strive to establish an organic whole during his production of the novel. Of course there are other important details to point out, but for the sake of the discussion we limit ourselves to these few points.

\subsection{Brooks and the Idea of Textual Harmony}

Another critical essay on the subject matter of organic unity was published in the book The Well Wrought Urn: Studies in the Structure of Poetry. The book is a series of critical essays written by American critic Cleanth Brooks, and in general it is about reading poems and how should critics approach an analysis of a poem. Although, one would argue that Brooks' theories are only applicable to poetry and not fiction -and in result they do not relate to the subject matter of our discussion- but like James, Brooks' standpoints about literature -in general- are important for us. The book contains eleven chapters and its most important chapter, at least for us, is the last one which is entitled by the author as "The Heresy of Paraphrase." The method of Brooks' criticism of poetry is the close reading of the poem.

Brooks argues that because a poem is an aesthetic whole, therefore "the relation between all the elements must surely be an organic one" (Brooks, 1947, p.183), and the implications of the poem or the poet's intentions cannot be found in the individual examination of each single element, hence the poem should be judged and criticized as a whole, and in this respect he argues that the act of paraphrasing poem's text is like a heresy. He argues: "we see plainly that the paraphrase is not the real core of meaning which constitutes the essence of the poem" (Brooks, 1947, p.180). Here, he mentions the word "essence," and by using this word we simply can understand that what Brooks means as the essence of the poem, or the literary work in general, is the organic whole which the creator, here particularly a poet, intends to create and the act of paraphrasing will reduce the denotations and mainly the connotations which one can derive from the text.

Like James, Brooks believes that a particular element or object cannot solely stand for the beauty of the work, but it can be helpful when this single element works in "harmony" with other elements of the work; he writes: "we must draw a sharp distinction between... a particular item ...and the beauty of the poem considered as a whole" (Brooks, 1947, p.178); and the artistic and beautiful arrangement of all elements can make certain impact which shows itself in the wholeness of the work, which is the organic unity of the work. He asserts that a glorious poem does not unify the same things with one another, on the contrary a poem can be called glorious when it "unites the like with the unlike" (Brooks, 1947, p.179). By uniting the like with the unlike, Brooks emphasizes on the concepts such as irony, paradox, and ambiguity; and of course these elements can produce the estrangement impact on the reader and we should note that New Critics were overemphasizing on the use of literary devices such as irony and paradox, and of course one of their pioneers is William Empson ${ }^{3}$ which wrote a book of the concept of ambiguity.

Brooks States that -and in this matter we can say that he is very close to what James expects of a well-written fictionthe poem should be the "experience," not talking about certain experience. In general, he tries to claim that the poet should capture the form, as well as the mood; because the basis of a poem should be reality and real life, and a poet can be called successful who mixes the essence of reality with the perfect form. He maintains that "the poem, if it be a true poem, is a simulacrum of reality [...] by being an experience rather than any mere statement about experience or any mere abstraction from experience" (Brooks, 1947, p.194).

\section{Maintaining the Organic Unity in Daisy Miller}

In the introduction to Daisy Miller, Elizabeth Hardwick writes that the novella can be read "as an intramural battle between middle-aged, deracinated American women" which have been "long abroad" and "a young, provincial American girl whose naturalness and friendliness are more suitable to hometown streets" rather than to the "mysteries of European society" (Hardwick, 2002, p. xi). Indeed, it is a trilateral battle between the discreet American expatriates, indiscreet American immigrants, and the mysteries of the European society. Winterbourne's role is crucial in this battle,

\footnotetext{
${ }^{3}$ Sir William Empson(1906-1984) was an English literary critic and poet who was emphasizing on the close reading of the text. Empson's most ground-breaking contribution to the literary society was Seven Types of Ambiguity. It was published in 1930 .
} 
because he is a spectator who observes both sides of the battle with a conscience to help him judge all the characters. But as the battle between the old and the new continues, Winterbourne is forced to pick a side which at the end left his conscience mortified.

The narrative starts by the meeting of Winterbourne with Daisy's little brother, Randolph. Winterbourne was very amused by the quick replies of the child and "wondered if he himself had been like this in his infancy, for he had been brought to Europe at about the same age" (James, 2002, p.6). Winterbourne quickly notices that something is different about this child and his own infancy; maybe he does not expect from an eight-year-old boy to be so bold. Winterbourne notices certain peculiarities in the kid's behavior.

In Winterbourne's first encounter with Daisy, the author mentions that in "Geneva, as he had been perfectly aware, a young man wasn't at liberty to speak to a young unmarried lady” (James, 2002, p.7), but because there were in Vevey and Winterbourne was well aware of the conditions, he thought it is the best place for flirting with a young, innocent flower like Daisy. Here the author intentionally claims about the awareness of Winterbourne to suggest that, unlike Daisy, he is a man of discretion.

Later in the narrative, Winterbourne describes Daisy's habits and manners formless, as if she has "no idea whatever of form" (James, 2002, p.9). Living a great amount of his life in Europe, Winterbourne promptly understands the crudity of Daisy's mannerism. "It was many years since he had heard a young girl talk so much" (James, 2002, p.11). Well, it is true that Daisy is an ignorant girl, but James also reveals to the reader the other character's mannerism, which is being too judgmental about Daisy. As Winterbourne puts it himself, he tries to formulate everyone and Daisy's behavior is a mystery because he could not "generalize" her. More or less, "all the characters in Daisy Miller: A Study judge people according to presuppositions of type" (Haralson \& Johnson, 2009, p.223). Of course, Winterbourne is the representative of the judgmental Society of American expatriates.

The interesting thing happens a few paragraphs later. After the author introduces both the examiner and the examinee, Daisy reveals her problem with Europe to Frederick. She asserts: "you see the most frightful things here. The only thing I don't like [...] is the society. There ain't any society - or if there is I don't know where it keeps itself. Do you?" (James, 2002, p.12) Daisy unintentionally reveals to the reader that this judgmental society has already decreed their verdict against Miller family and it is Daisy's childish innocence that keeps her from understanding such a thing.

Daisy tells Frederick that, back in Schenectady, she had "a great deal of gentlemen's society." Winterbourne is "amused" and "perplexed," but "above all he was charmed;" because he had never "heard a young girl express herself in just this fashion" (James, 2002, p.13). The fact that Winterbourne is more charmed than being perplexed by Daisy's confession implies that Winterbourne is more in favor of "studying," or as Motley Deakin puts it, Winterbourne "typifies" her. James intentionally reveals an important side of Winterbourne's character; he is not in passionate love with Daisy, instead he is the sort of man who prefers to be a bystander and categorizes women. James immediately delays the narrative to talk about the previous experiments of Winterbourne in Europe:

He had known here in Europe two or three women-persons older than Miss Daisy Miller and provided, for respectability's sake, with husbands- who were great coquettes; dangerous terrible women with whom one's light commerce might indeed take a serious turn. But this charming apparition wasn't a coquette in that sense; she was very unsophisticated; she was only a pretty American flirt. Winterbourne was almost grateful for having found the formula that applied to Daisy Miller. (James, 2002, p.13)

We understand that Frederick engaged in some affairs in the past and maybe the results of them were not good for his reputation, so he prefers to be a bystander rather than to engage him-self in a passionate affair. Winterbourne cannot decide "whether Daisy is vulgar or naive," and therefore he is "perturbed when Daisy does not fit into either of these boxes, but instead of reassessing his methods, he cuts Daisy down to size" (Haralson \& Johnson, 2009, p.223) and then he is relieved to declare that Daisy is only an unsophisticated, American flirt; because Winterbourne is such a cautious person, as if Daisy was a sophisticated coquette, he would hold back all his desires to talk to her. Motley Deakin noticed the same manner in Winterbourne and claims that Frederick's habit is to "categorize; he sees the type, not the individual. When Daisy first appears before him, his response is not "How pretty she is," but "how pretty they are. [...] unwilling to accept her in her charming uniqueness, he searches for a term to typify her" (Deakin, 2001, p.80). Deakin investigates further in the habits of Winterbourne. He argues that Winterbourne does not attach him-self with the object of his investigation; also, "he approaches his interests with this habit of making comparisons, even to the extent of trying to balance the attractions of the Italian cities Bologna and Florence against those other, quite different charms of Daisy" (Deakin, 2001, p.80). Deakin maintains that Winterbourne commits him-self to Daisy because he thinks this is a proper thing to do. He is not in pursuit of either love, or passion; and he always puts his footsteps on the safest routes in the society. He writes:

Winterbourne's purpose is to please his fancy, not to stir his soul. His attitude is mild, suggesting that he is committed because he thinks it is the proper thing to do rather than because he feels any great passion. His interests involve very little personal risk. Even his attraction to the pretty but socially déclassé Daisy leaves no blemish on him. (Deakin, 2001, p.80) 
There are other clues which James puts in the story in order to develop its organic unity. After reading another few pages, the reader understands that the narrative stays with Winterbourne rather than staying with Daisy. As the full title of the novella suggests, Daisy Miller "A Study," the story is more about the judgments and opinions of others, rather than a self-revelation of the character. And one can observe that this aspect of the work has masterfully done. "The observing outsider is a common figure throughout James's work, and the strictness with which Winterbourne's narrative viewpoint frames Daisy's story is an important development in James's narrative technique." James focalizes "the narrative within the consciousness of a single character." The story takes place in "Winterbourne's consciousness and implies the possibility of competing interpretations of Daisy's character and conduct. Readers must first evaluate Winterbourne's point of view in order to understand Daisy" (Haralson \& Johnson, 2009, p.223). Maybe, "it is only the fortune hunter Giovanelli," who observes "society with some objectivity, is able to sense that Daisy is "the most innocent' of creatures who simply does what she likes" (Coffin, 1958, p.273).

Winterbourne who was perplexed and confused by the words which Daisy uttered at Vevey, easily understands his aunt's intention by the tone of her voice. "He at once recognized from her tone that Miss Daisy Miller's place in the social scale was low" (James, 2002, p.18). It is true that Winterbourne's logic classifies the object of his scrutiny by making comparisons; and if the reader exploits the same logic as Winterbourne, he will understands that Frederick who spent quite a while to understands Daisy's intentions -at least Winterbourne thinks that he has succeeded to classify Daisy at this point of the novel- does not even have to wait to understand his aunt's intention and the fact that James uses the words "at once" is a proof for such understanding. There are other examples of Mrs. Costello's judgmental characteristics; After Frederick mentions Miller family to his aunt, Mrs. Costello retorts that Miller family is "horribly common. [...] they are the sort of Americans that one does one's duty by just ignoring" (James, 2002, p.18). Here, James again emphasizes on the concept of categorizing. From here to the end of the story, the text contains lots of ironical situations. Mrs. Costello, like Frederick, categorizes these new immigrants by using the word "sort," but at the same time the author hints us that she and her nephew can be categorized as the enclosed, American expatriates. Mrs. Costello refers to Daisy as the "young lady" who has an "intimacy with her mama's courier." And Winterbourne asks from his aunt that does she believe that their intimate relation to be true? His aunt replies that "There's no other name for such a relation. But the skinny little mother's just as bad! They treat the courier as a familiar friend-as a gentleman and a scholar" (James, 2002, p.18). Aunt Costello exploits the word intimacy, because above all "intimacy" connotes the sexual friendship rather than a simple one; but we can observe that her explanation for the word is not quite fit. This is ironical because indeed other names are available for such relations.

After introducing another American expatriate, James develops both ironical and sarcastic tone. James, very much a meddler in the narrative, comments that "Winterbourne listened to these disclosures" (James, 2002, p.18) and this is truly sarcastic because what James call as disclosures -and Frederick listens with interest to- are the blathers of an old lady, and cannot be considered as facts. The reader knows already that this is the blathers of an old woman, because James has already told the reader that Mrs. Costello has sporadic headaches that keep her from going outside too often; so again this is ironic because if Mrs. Costello goes outside rarely, how can she disclose this amount of information about the Millers? Later in the story, Winterbourne remembers that he had heard that the daughters of Mrs. Costello her-self are called "tremendous flirts" back in New York, so immediately one understands that Mrs. Costello cannot be a good judge to rely upon.

As the story reaches its middle, James contrasts the lightheartedness and straightforwardness of Daisy's behavior with the discreet and ludicrous behavior of Winterbourne. After Daisy asks for a meeting with Mrs. Costello, Frederick hides the real reason that the aunt does not want to see Daisy; instead he tries to evade the situation by asserting that "She'd be most happy, but I'm afraid those tiresome headaches are always to be reckoned with." Daisy, who is too much lighthearted does not understand Winterbourne false excuse and insists: "Well, I suppose she doesn't have a headache every day." Winterbourne, who is trapped by the innocence of Daisy's manner, comes with the ludicrous justification that "She tells me she wonderfully does." Daisy which is a very straightforward girl, retorts that "She doesn't want to know me? [...] why don't you say so! You needn't be afraid! I'm not afraid!” (James, 2002, p.22) Author brings a situation which the straightforwardness of Daisy confronts with the timidity and the discretion of Frederick's mentality. Maybe it is easy for Daisy, who is not financially relies upon anyone but his father, to claim that she is not afraid, but for Frederick which presumably relies on his aunt in financial matters, the sentence "I'm not afraid" is a little bit too bold to say. Deakin notices the same thing and asserts that Winterbourne is a "captive of women" in some sense and being held captive results from his lack of "initiative." He writes:

Winterbourne is presented as the captive of women, not their protective gallant. He is "at liberty to wander about" when his aunt wishes to be alone with her headache. "He had imbibed in Geneva the idea that one must always be attentive to one's aunt," certainly in part because the code requires it, but also in part, one would suspect, because she was in control of the "social sway," [...]Winterbourne's nebulous means of monetary sustenance seems peculiarly vulnerable to a matriarchic image as overwhelming as Mrs. Costello. He is the captive as well of - or, one should say, "extremely devoted to"-a mysterious, older, foreign lady in Geneva who, with her erotically ambivalent significance, seems a most satisfactory and safe choice - if he indeed made the choice-for one so lacking in initiative as Winterbourne. (Deakin, 2001, p.80-81)

Later, when Winterbourne accompanies Daisy to castle of Chillon, the reader is forced to notice the difference between Daisy's actions and those in her surroundings. "Miss Miller was highly animated, She was in brightest spirits;" what 
shocks Winterbourne is that-unlike him- Daisy does not have a bit of shame or nervousness. "She was clearly not at all in a nervous flutter-as she should have been to match his tension; she avoided neither his eyes nor those of any one else; she neither coloured from an awkward consciousness when she looked at him" (James, 2002, p.30). These descriptions suggest that Daisy is not an "American flirt" in the sense that Winterbourne believes her to be. She is a simple girl, maybe uncultured, that is really a free spirited and likes to experience life in her fresh and youthful way, but although Daisy does not care about her surroundings, people "look at her a great deal." And this implies that natural actions of Daisy were under scrutiny by the old, watchful European society.

Another concept which contributes to the organic unity of the work is the amount of information that the author dedicates to each character. All the characters -more or less- are viewed from the window of Winterbourne's mind; but what about Winterbourne him-self? James intervenes in the narrative to assert a point or so about Winterbourne, but the thing which is noticeable is that there are certain times in the story that James prefers not to give extra information to the reader, in order to add mysterious and secret atmosphere to his narrative. A very bold example from these sorts of mystifications can be observed here:

Winterbourne was certain that nothing could possibly please him so much, but that he had unfortunately other occupations. [...] The young man allowed that he was not in business, but he had engagements which even within a day or two would necessitate his return to Geneva. (James, 2002, p.32)

James deliberately does not comment on the affairs and obligations of Winterbourne. And these obligations remain mysterious through the novel. One can assume that the author does not want to demolish the organic unity to astray and talk about Winterbourne's affair. This assumption can be correct, but if we compare the amount of details which we derived from Daisy and other minor characters like Daisy's father, with the amount of information which we know from Winterbourne -which is the main protagonist- we immediately understand that James has an intention for hiding certain facts about Winterbourne's life. The reader knows that Winterbourne has some engagements back in Geneva that perhaps involves an unknown, mysterious and presumably not young, European lady. As we strive to understand more about Winterbourne's life, James also makes us ponder that, do we really know anything about Daisy at all? As we take for granted every piece of information which we derive from Daisy's life as a mere fact, it is very true that we really do not have enough information even about Daisy at all. Winterbourne is our observer which is a "misshapen assessment" to us. This tactic from James serves beautifully to the concept of organic unity, because at the end, Winterbourne understands that his logic did not apply to Daisy and he was wrong about her. "It was on his conscience he had done her injustice" (James, 2002, p.71). But the organic unity which James has created already serves the reader best; because for the reader the state of Winterbourne's affairs is a mystery, so how can the reader trust a person like Frederick who hides his life from the reader? Winterbourne cannot be a truthful and trustworthy person to rely upon. Robert Weisbuch has noticed the same thing and asserts that

Daisy's continuing and finally ennobled simplicity is not what we usually expect from fiction, where characters generally complicate themselves in the course of their experiences. But James means for us to see Daisy's complexity as not inherent. The terrible ambiguity, the vexing mystery of her status as innocent or vixen, have nothing to do with her inherent quality, simple as a Daisy can be; they are all evoked by Winterbourne's misshapen assessment. It is not really her story but Winterbourne's, and there the complications are killing. (Weisbuch, 2001, p.82)

When Daisy goes to Rome, these killing complications seem to aggrandize rather than to lessen. Mrs. Costello who previously tried to beguile the reader about being disinterested in Daisy's life, reveals to Winterbourne that in the time when Frederick was at Geneva, Daisy became "very intimate with various third-rate Italians, with whom she rackets about in a way that makes much talk" (James, 2002, p.35). The Kind of words that Mrs. Costello uses through the story shows that she is pretty much exaggerating everything she says about Daisy. She claims that Daisy has intimate relationship with "various" persons, but as the story continues the reader discovers that Daisy has only a friendship with an Italian called Giovanelli. James, little by little, increases pressure on Daisy. Another description which is available in the text is the time when Daisy walks with Giovanelli and Winterbourne in Pincio; James writes: "The slow-moving, idly-gazing Roman crowd bestowed much attention on the extremely pretty young woman of English race who passed through it, with some difficulty" (James, 2002, p.42). The fact that Roman crowd is "slow-moving" hinders Daisy from being joyful -and in consequence- and blissful as well. The pressure aggravates when Mrs. Walker tries to force Daisy to leave Giovanelli at Pincio. "It's really too dreadful. [...] That crazy girl mustn't do this sort of thing. She mustn't walk here with you two men. Fifty people have remarked her" (James, 2002, p.46). Having failed to bring Daisy back, Mrs. Walker forces Winterbourne to leave Daisy at Pincio. Finally, Mrs. Walker insistence makes Daisy annihilate herself in front of Winterbourne and Giovanelli and she confesses that "I'm all improper" (James, 2002, p.48).

What is crucial to our understanding of the novella is that, James achieves organic unity without stating anything too boldly about any character. He meddles in the story, but only to the extent which reveals to the reader certain aspects of the characters. He tries to efface him-self from any bold comments about Europeans or Americans, and that is the thing which makes him a master of his art. As we studied his revolutionary essay "The Art of Fiction," we can see that there is no contradiction between what he claims in his essay and what he writes in his work. What makes his fiction to be so close to reality is that he does not differentiate between "characters," "incidents," and "situations." He mixes every 
element and every aspect of his work together, so that the only thing which comes as a result is a piece of life rather than to be certain "moral" or didactic goal. Sarah Wadsworth asserts that James is so skillful in his work that only a veteran reader can decipher and judge characters. She writes:

So skillful is James in presenting the story through the eyes of this erring youth that the values and judgments of the supercilious, hypocritical American colony to which he is attached seem almost to become normative as one reads the novella. Indeed a survey of the criticism and scholarship on Daisy Miller suggests that only gradually have readers shaken off the prejudices of this close-knit clique and made way for generally positive and sympathetic readings of Daisy's character, along with more clear-sighted and skeptical interpretations of Winterbourne's. (Wadsworth, 2008, p.33)

\section{Conclusion}

Although we cannot call James a pure Formalist, but without doubt his ideas in writing have certain similarities with the Formalists who succeeded him. The Concept of Organic Unity is the very example of this affinity which is claimed by both James and Brooks. We observed that how James exploits literary devices such as Irony in order to maintain the organic unity, and form a story around the central theme. Irony, which is a key device in the theories of 'New Critics,' helps the author to deliver his story with artistry. We observed that how James' ideas of fiction, discussed in "The Art of Fiction," conform with his own writing actually; and he writes similar to what he claimed in his revolutionary essay.

\section{References}

Brooks, C. (1947). The Well Wrought Urn; Studies in the Structure of Poetry. New York: Reynal \& Hitchcock.

Coffin, T. (1958). Daisy Miller, Western Hero. Western Folklore, 17(4), 273-275. doi:10.2307/1496191

Deakin, M. (2001). Motley Deakin on Winterbourne. In H. Bloom, Henry James (1st ed., pp. 79-81). Broomall, PA: Chelsea House Publishers.

Encyclopedia Britannica,. (2015). organic unity | literature. Retrieved from http://www.britannica.com/art/organic-unity Haralson, E., \& Johnson, K. (2009). Daisy Miller: A Study. In Critical Companion to Henry James: A Literary Reference to His Life and Work (1st ed., pp. 218-228). New York: Facts On File.

Hardwick, E. (2002). Introduction. In H. James, Daisy Miller (1st ed., p. Xi-Xvii). New York: Modern Library.

James, H. (2002). Daisy Miller. New York: Modern Library.

. . . . . . (2010). The Art of Fiction. In V. Leitch, The Norton Anthology of Theory and Criticism (2nd ed., pp. 744759). New York: W.W. Norton.

Quinn, E. (2006). Organic Form. In A Dictionary of Literary and Thematic Terms (1st ed., p. 306). New York: Facts On File.

Wadsworth, S. (2008). What Daisy Knew: Reading Against Type in Daisy Miller: A Study. In G. Zacharias, $A$ Companion to Henry James (1st ed., pp. 32-50). Malden, MA: Wiley-Blackwell.

Weisbuch, R. (2001). Robert Weisbuch on Winterbourne and the Doom of Manhood. In H. Bloom, Henry James (1st ed., pp. 81-83). Broomall, PA: Chelsea House Publishers. 